\title{
中国における坐の様式の変遷過程に関する研究 \\ A STUDY ON CHANGING PROCESS OF SITTING STYLES IN CHINA
}

\author{
李 斌*1, 舟橋 國 男*2, 奥 俊 信*3, 鈴木 毅*4 \\ 小浦久子*5, 木多道宏*6 \\ Bin LI, Kunio FUNAHASHI, Toshinobu OKU, \\ Takeshi SUZUKI, Hisako KOURA and Michihiro KITA
}

\begin{abstract}
It is known that, in ancient China, the sitting styles changed from sitting-on-floor to sitting-on-chair. But the time of turning-point of sitting-on-chair has not been ascertained yet. By dividing into 4 stages, namely, "Age of Sitting-on-Foor", "Appearance of Sitting-on-Chair", "Expansion of Sitting-on-Chair" and "Generalization of Sitting-on-Chair", this study tries to clarify the changing process of sitting styles themselves and its reasons. With the change of sitting styles, the floor structure of building also changed. From the point of view of sitting style, this study tries to clarify the relationship between the change of this behavior style and the change of architectural environment.
\end{abstract}

Keywords: sitting style, sitting-on-floor, sitting-on-chair, floor structure 坐の様式、床坐、椅坐、床の構造

\section{1. 研究背景}

現在、人々の日常生活が椅坐の姿勢で行われている国・地域は多 数を占めている。床坐の姿势を取り入れているのは、日本、韓国、 インド、アフリカの一部など少数の国・地域である。日本では、近 代における、椅子式の家具とともに、椅坐が日常生活に導入され”、 従来の床坐に適した座式〉)住宅様式、室内のしつらい等は大きく 変わってきた。現在に至るまで、床坐への回帰の動きもあったが゙， 今日では、床坐と椅坐とが混在している状況である。

日本において、坐に関する既往研究は数多く見られる。

入澤達吉は、日本人の坐り方を分類した上で、「日本流の坐り方」 が、元禄享保頃から採用されたのではないかと推測した。又、医学 の角度から、「日本流の坐り方」が身体にどのように影響を及ほし たのかを検討しだ)。

山折哲雄は、世界中の様々な文化圈における坐る姿勢の類型を考 察し、日本における坐の文化・宗教的な意味に触れながら、現在に 至るまで坐の変遷を研究しだ)。

芦原義信は、日本の建築特に住宅における、靴を脱ぐという行為 から見た「内」・「外」の空間領域上の特徵と日本人の空間意識に ついて研究じ，さらに、日本の建築が西欧の建築とは異なって、 「床の建筑」であり、床に坐っていることが「床の建築」と哚い関
わりをもっていると指摘しだ。

近年、住宅における坐の様式に関する研究も数多く見られる。こ の中で、例えば、沢田知子は、日本の戸建て住宅における、椅坐 · 床坐に関する起居様式の具体像、しつらいの配置形態、居室構成上 の特徵を研究し、住宅計画の今後の課題に奇与した ${ }^{8)}$ 9) 。

近代における日本の住み方は、ある意味で、坐の様式と関わりな がら変容してきたのであるが、中国の事情は日本と違い、住み方は 椅坐が定着されている前提で変容してきた。中国では、現在一部少 数民族の地区を除き、ほとんどの地方で、椅坐の様式で日常生活が 行われているが、これは昔から、一貫して続けられてきたのではな い。漢民族を中心にした中国では、長い歴史の流れの中で、坐の様 式は床坐から椅坐へ変遷したのである。

劉敦楨は、漢代に宮殿・住宅において床坐と履物を履き替える様 子を説明し、むしろに坐る床坐の終結は唐代であろうと推測した ${ }^{10)} 。$

藤田豊八は、「胡床」”' が古代中国に入った時期を考証し、 「胡休」の使用に伴って椅坐が導入されたきっかけが、漢民族と西 北騎馬遊牧民族との交流であったと指摘した ${ }^{2)}$ 。

劉敦楨は、建築史の角度から坐の様式の変遷に関わった居室建築 空間及び室内家具陳列方式の変遷を研究したが、坐の様式自体の変 遷過程の具体的な経緯については触れなかった。しかも、椅坐への
*1 大阪大学大学院 博士後期課程 $\cdot$ 工修

*2 大阪大学大学院工学研究科建築工学専攻 教授. 工博

*3 和歌山大学システム工学部環境システム学科 教授・工博

*4 大阪大学大学院工学研究科建築工学尃攻 助教授・工博

*5 大阪大学大学院工学研究科地球総合工学尃攻 助教授・工博

*6 大阪大学大学院工学研究科建築工学専攻 助手. I博
Graduate School of Engineering, Osaka University, M. Eng.

Prof., Osaka University, Dr. Eng.

Prof., Wakayama University, Dr. Eng.

Assoc. Prof., Osaka University, Dr. Eng.

Assoc. Prof., Osaka University, Dr. Eng.

Research Assoc., Osaka University, Dr. Eng. 
定着時期については、概ね、300 年余りの両束時代にあたると指摘 した ${ }^{13)}$

また、南北朝には床坐で、椅坐への変遷は唐・五代にあたるとい う説もある(4) 。

朱恵良は、古代中国において坐臥の道具としての「席」い．

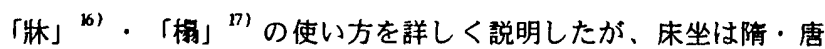
以前で、椅子に坐る椅坐は末代以後に流行したと論じた ${ }^{18)}$ 。

\section{2. 研究目的・意辣・方法}

中国における、床坐から椅坐への変遷経緯、特に椅坐の定着時期 については未だにはっきりされていない。本研究では、中国におけ る床坐から椅坐への変要過程を明らかにすることを目的とする。坐 の様式は、時間軸に沿って渐進的に変化しており、説明上の区分と して、本研究では、中国歴史上の時代の順に、「床坐の時代」、

「椅坐の出現」、「椅坐の拡大」、「椅坐の定着」の四段階に区分 して、坐の様式及び変逗要因について探究する。なお、坐の様式の 変㬊に伴い、建築の床の構造の仕組みも変化し、また、本論では詳 述しないか、坐の様式の変選に伴う家具類の変化も認められ、長い 時間軸の中で、これらの要素がどのように相互に影㛺、浸透したの

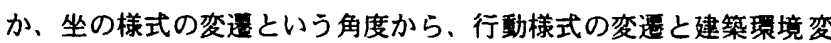
化との関倸の解明を試みる。

これらの変僄の背景となった社会・経済・文化面での事情は、も ちろん、現代社会とは異なるのであるが、これら坐の様式の変遥 と その要因の解明は、生活行動様式理解の一助となろう。

本論では、考古学資料、絵画、文献記録などの調查によって、研 究を行う。なお、中国古文を引用する場合、全文を訳する必要性は 少ないため、本研究に関した部分に下線を施し、その前後の文脈を 含めた日本語の説明を〈 ）内に示す。

\section{用語定耤}

坐 : 現代日本語では、「すわる」とは「座る」にしているが、 「坐る」を使用した既往研究も数多かった。中国語では、「坐」と は「すわる」の意味で、「座」とは席の意味である。本論では、 「坐」を含めた中国語の古文を引用するため、「すわる」には「坐 る」を使用する。

床坐：佅面を身体支持具として暗部を支えて坐る姿妿である。正 坐、胡坐、立て膝坐などがある。

椅坐 : 高座家具（椅子、腰掛け、垵台等）を身体支持具として 部を支え、すねが大腿とほほ直角になり床面に垂れて坐る姿勢であ る。椅子の上で床坐の姿势をとる場合、即ち、身体支持具を床から 椅子に変えただけのものは椅坐とは言えない" ${ }^{19)} 。$

坐の様式 : 床坐と椅坐との総称である。

\section{3.中国における坐の溙式の変进}

\section{3-1.床坐の時代}

殷商（約紀元前16～前11世紀）時代、甲肯文の「席」は图、 「宿」は)は囟と茟かれた。当時、室内では、「席」が敷かれ、 人々が「席」に坐っていたと考えられる゙1)。

西周（約紀元前 11 世紀～前770 年）、春秋（前770年～前476年） 時期、竹製のむしろである「䇥」の上に「席」を教き、室内で坐る 家具として坐られた。坐る家具は、商代の寝台、「案」そ)を加え、
「幾」 ${ }^{23)}$ 、屏風も出現した ${ }^{24)}$ 。

「論語」の中に、孔子の起居行動について、“席不正，不坐。”

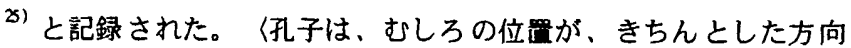
に向いていなければ、坐らない〉。春秋時代、人々が「席」の上に 坐っていたことが分かる。

戦国（前475 年〜前 221 年）から、秦（前221年〜前206年）、漢 （前206年〜220年）にわたって、床坐の習帻が維持され、「幾」、

「案」、睡眠の寝台の高さは低かった。

「荘子」の中に、“南郭基、嗳幾而坐、仰天而嘘。”26)の記 録があり、〈南郭子基が时掛けにもたれて坐り、大空を仰いで太い 息をはいた〉。戦国時代の床坐の様子が分かる。

漠代前後から、寝台が日常起居と応接にも使用されるようになっ た。しかし、この種の赛台（「㨨」）は相対的に小さく、普通、一 人だけで坐った。叟台の後方とそばには、低い屏風が立てられた。 図1に示したように、漠代貴族夫婦の飲食・談話の場面から、当時 の床坐の様子が窥われる。

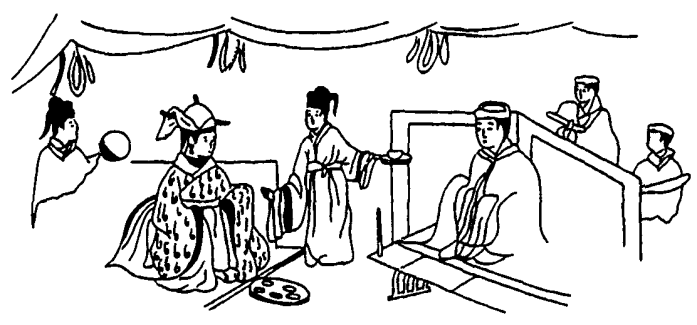

図1 東漢の床坐の様子 ${ }^{27}$

西漠、皇族の日常生活における床坐については、以下のような記 録があった。“趙飛燕女弟居照晹殿……中設木草屏風……幾玉床、

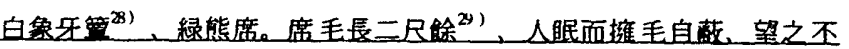
能見、坐則没憷其中、雑悪諸香、一坐此席、賖香百日不歇。”30) (西漢成帝（紀元前32年～前8年）頃、趙飛燕の妹は照陽殷に住み、 ……宮殿の中央には木製の絵の描かれた屏風が立てられ、玉机、玉 寝台、白象牙で編んだむしろと黒熊の皮製のむしろがある。むしろ の毛の長さが四十センチ以上で、人が赛ると毛に埋まり、姿も見ら れなくなる。坐ると膝も見られなくなる〉。西熯当時、人々は「席」 に贯るもしくは坐るということが分かる。

坐る姿勢については、以下の文献にも明产されている。“管蜜自

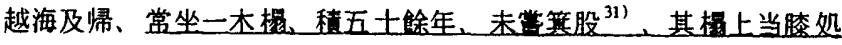
皆空。”32) (東漢末期、読書人の管掌が一つの木製の棈に常に坐 り、五十年余りを経て、足を投げ出して坐ったことがなく、滕のあ たったところがすへて破れた〉。坐る姿势が跪いて坐るもの（もし くは「箕股 )で、坐る家具が「㛫」であったということが分かる。 林坐の坐法の種類について、坐・跪・居・算股があった

\section{3-2. 椅坐の出現}

三国（220年～280年）、両晋（265年～420年）、南北朝（420年 〜589年）では、「席」と「㛫」の上に床坐の習慣が継繶されてい た。当時の彊女の起居生活が描かれた絵画から、「席」と「柯」の 上で行われた床坐の様子が見られる（図2、図3）。 


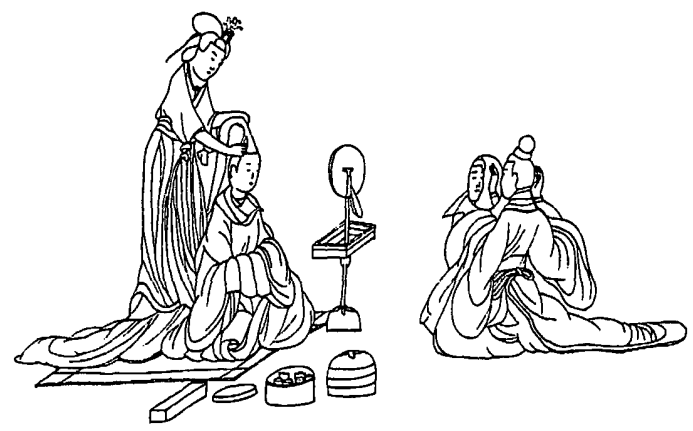

図2 東晋の床坐の様子 ${ }^{34)}$

しかし、東漢末期から、北西少数民族によって次第に「胡床」と 高座家具が伝えられ、上流階層で徐々に使われてきた ${ }^{35) 。 こ れ ら ~}$ の高座家具とともに、椅坐の様式も伝えられてきた。これが、唐代 以降床坐から椅坐に変わる端緒となったと考えられる。

図4は、北西少数民族の生活の様子を反映したと考えられる早期 敦煌壁画の中、二人の少数民族の男性が「胡床」に坐り、談話中の ようである。図5は、一人の漢民族の僧侶が床坐の姿勢で、椅子に 坐り、犋想しているようである。同時に、漢民族の就寝用の寝台及 び起居用の寝台（「㛫」）の高さが高くなるのに伴い、寝台の上に 坐る時、足が地面まで垂れ、椅子坐の姿勢を取り入れやすいように なった（図6）。

「胡床」が持ち運びやすいため、漢民族の戦場にも使われるよう になった。“(戴) 淵在岸上、据胡床指塺左右、皆得其宜。”36)

〈西晋、戴淵が岸にあって胡床によりかかり、左右のものを指揮し ていたが、そのやり方がすべて宜しきを得ていた〉。

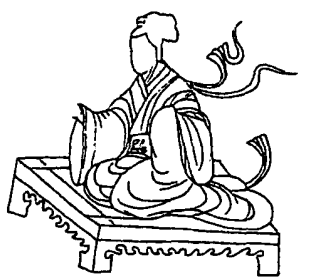

図3北魏の床坐の様子 ${ }^{37)}$

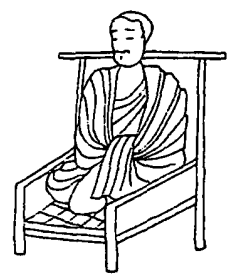

図5西魏の坐の様子 ${ }^{39)}$

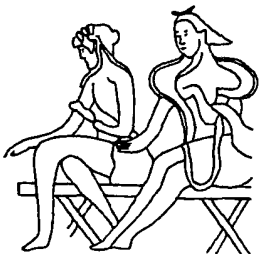

図4 北魏の椅坐の様子 ${ }^{38)}$

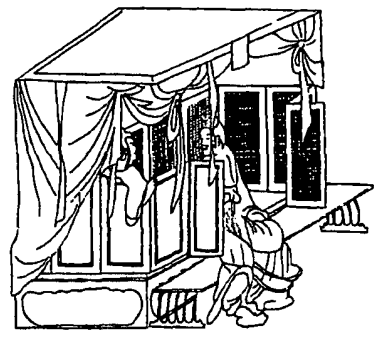

図6 東晋の椅坐の様子 ${ }^{40)}$
隋（581 年〜 618 年）、唐（618 年～907 年）にかけて、床坐の姿 勢と起居用の寝台の使用は、まだ主流として広く存在していたが、 足を重らす椅坐の様式は上流階層に広がってきた。唐代、床坐と椅 坐を併用した様子は当時、婦女らの日常生活の様子が描かれている 絵画から見られる。図杖、宮廷の婦女らが「席」、もしくは椅子・
腰掛けに坐り、休憩・談話しているような場面である。椅子に坐つ た婦女の身分が最も高いと考えられ、椅子が高い身分の象徵にも使 われた。図8は、宮廷の婦女が腰掛け、もしくは「席」に坐り、針 仕事をしている場面である。図9は、家庭で婦女らが寝台に坐り、 話し合っている日常的な場面である。

興味深いのは椅子に坐っても、床坐の姿勢を取り入れた場合もあ り、必ずしも椅坐ではないことである（図5と図9参照）。
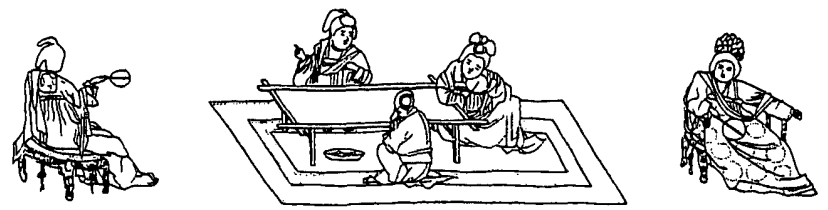

図7 唐の坐の様子 ${ }^{41)}$

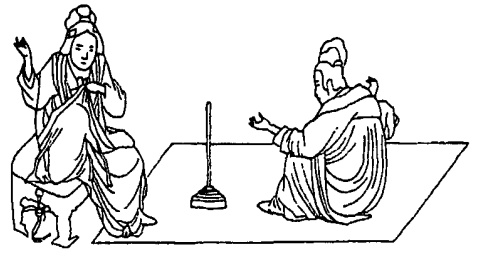

図8 唐の坐の様子 ${ }^{42)}$

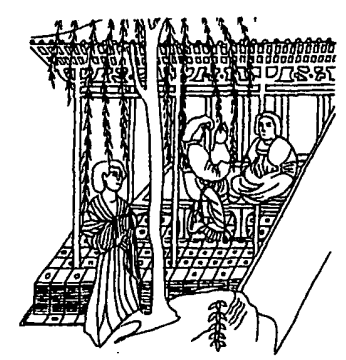

図9唐の坐の様子 ${ }^{43}$
唐代になると、椅坐と深い関係を持っている椅子についての記録 も現れてきた。

“（顔魯公）奉使李希烈，春秋七十五矣。臨行……命取席固圆其 身, 挺立一躍而出。又立两藤倚子相背, 以再手握其倚処, 愁足点空, 不至地三二寸，数千百下。” 44〉顔真卿は李希烈へ派遣された時 に、すでに七十五歳になった、……つの藤製の椅子を相背にさせ た…ㄱ.ここれは椅子に関する初見の記録であり ${ }^{45)}$ 、顔真卿が李 希烈へ派遣されたのは建中4年（783年） ${ }^{46)}$ 故に、8世紀末までには 椅子が用いられていたことが窥われる。

その後、“貞元十有三季（797 年）、……北海壇二所新犆祭器及

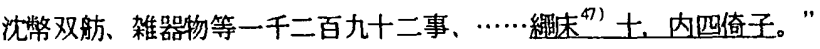
48) 〈唐代の797年、北海壇祭事の時、新しい供え物は1292件で、胡 床が十個、椅子が四つある〉という記録もあった。

\section{3-3.椅坐の拡大}

五代（907年〜960 年）になると、「韓熙載夜宴図」に示された ように、上流階層の宴会の時、長方形の机、四方形の机、長方形の 腰掛け、丸の腰掛け、丸の椅子等色々な形の家具が登場し、後代の 椅坐家具類型は、唐代末期・五代に大体そろっていた。高座家具と 椅坐の様式は普及していた。床坐と椅坐とが併用され、床坐の家具 は、「席」でなく、寝台だけとなった（図10）。

北束（960年〜1127年）時期、以前より多く現れた一般庶民の日 常生活を主題とした絵画から、その椅坐の様子が分かる。図11は、 北末の一般家庭の婦女が、腰掛けに坐り、赤ちゃんのからだを洗っ ている日常的な場面である。図12は、婦女らが、寝台に腰掛け、絵 画を鑑蒷している日常的な場面である。 


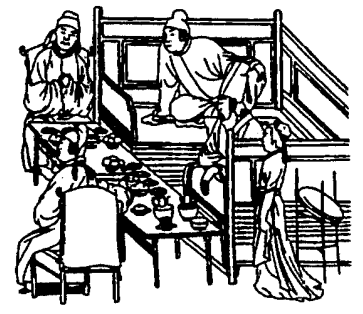

図10五代の坐の様子 ${ }^{49}$

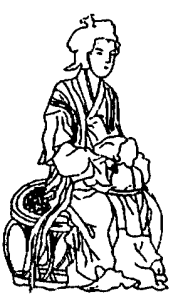

図11 北末の椅坐の様子 ${ }^{50}$

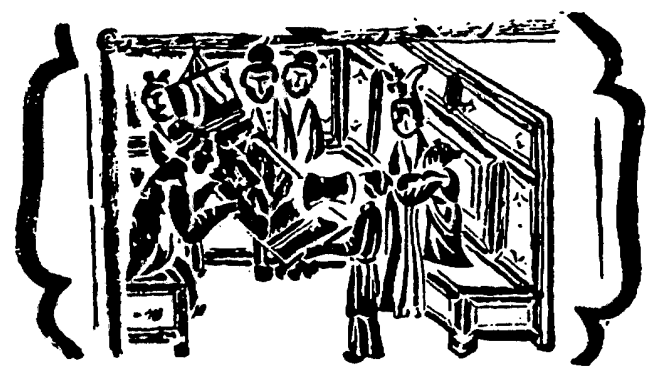

図12 北宋の椅坐の様子 ${ }^{511}$

五代・北宋初期にかけて、椅子に関する文献記録はさらに数多く 見られる。

“同光三年（925年）九月十日、特然修換、材木皆新，佣上有阿 留陀佛一聖僧一坐、倚子一双。” 52)〈五代の後唐の925年9月 10日、寺の建て替え工事の後、二つの椅子が監かれた〉。

“天福八年（943年）秋，出帝幸大年生還，置酒延廣第。延廣所 進器服、䗆馬、茶床、椅椙皆衰金銀，飾以龍鳳。”53) 〈五代の後 珰の943年、皇帝が景延廣の家を訪れ、最延廣が皇帝に食器、衣類、 荌具、椅子、榻を献上した〉。

“儀尚本燕人…… (周) 世宗時為翰林学士……祖改明徳門 為乾元門……儀因於堂前彫起花椅子二只。” 54) (北末初期、宾倿 が宅の前に模様のついた椅子を二つ彫り上げた〉。

さらに、北初期、上流階層において、椅子等の家具が応接室に 使われるようになった。

“（徐）鉉遂徑往其居……老卒往報。徐入、立庭下。久之, 老卒 遂入取旧椅子相対，锌谣望見，洎卒日：但正衙一椅足矣。傾間，本 主紗帽道服而出，鉉方拜……主曰：今日豈有此礼。徐引椅少偋。乃 敢坐。" 55 〉〈北宋初期、徐鉉が李後主の家に直行した。待ってい る時、老兵士が古い椅子を二つ運び出した。徐鉉がご主人に一つだ けで結構だと言った。しばらく経つと李主人が出てきて、徐鉉が拝 んだ。本後主が今日ではそんな礼儀をやめろと言った。徐鉉が椅子 の方向を偏し、ようやく坐った〉。

“趙韓王西京起第、外門皆柴茾 ${ }^{56}$ ……犆事有椅子一双、样制古 朴，保坐分列，自勊王安排，至今不易。太祖幸洛，初見柴荊，既而

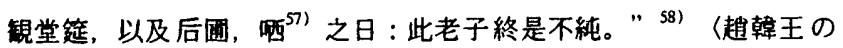
宅が洛陽の西に位置し、門戸の外にいばらのさくがあり、応接室に 笴子が二つあり、見た目が昔風らしく、韓王時期からずっと分けた まま圈かれている。末太祖が洛陽を訪れ、この榭、応接室の配罯、 奥の庭を見てから、この人に問題があるなあ、と笑った〉。北宋初 期、椅子はまだ通常のものではなかったが、上流階局の応接室に配 置されるようになったということが分かる。
また、北宋初期・中期、土大夫等の上流階層に椅坐が流行ってき たにもかかわらず、その家庭の媂女が椅坐にすることは珍しかった。

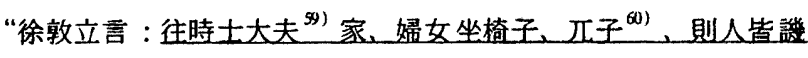
笑其無法度。梳洗床，火缩床家家有之。” 61)〈北宋初期 - 中期、 士大夫の家の㛿女が椅子、腰掛けに坐ると、みんなに笑われる。家 庭ごとに、化粧用の寝台、こんろ付きの寝台があった〉。寝台の上 で、化粧等をしていたことから、婦女らの坐る姿势は休坐に間違い ないと推定できよう。

北宋半ばにかけても、「韓熙載夜宴図」に示されたように、一人 が机と関係なく椅子に坐る、もしくはただ一人が机の前で椅子に坐 るという配昰方式がまだ見られる。椅子は単独に設置され、必ずし も机と併用されることにはこだわらなかったのである。

“平明舅姑坐於堂上，東西相向，各置卓子於前，替者見婦於舅姑， 婦北向拜男於堂下，執算，実以東粟，升自西階，進至留前，北向基

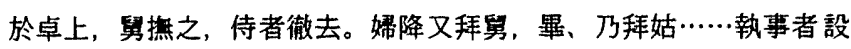

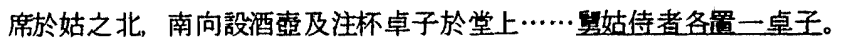

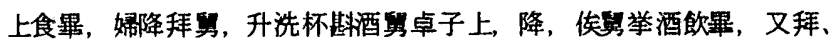
遂献姑，姑受而飲之，飲如献舅之儀。” 62) (筫姑が㐫接室に坐り、 東西対面で、各自の前に机が置かれている、……畕姑侍者の前に各 一つ机が膡かれ、食事をする〉。これは以前の「老学庵筆記」（注 ${ }^{61)}$ 参照）の記録と違い、士大夫の家の婦女が椅子に坐るようになっ た。これは北宋中期に現れたばかりの現象ではないかと思われる。

“(韓魏公) 特設一卓、覆以紼衣、致玉蓋其上，目将用之将酒，

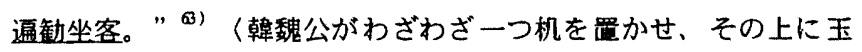
のコップを置き、坐っているお客さんたちにお酒を勧めた〉。必要 であれば机が臨時的に設置されたということが分かる。

この段階では、「席」の上の床坐の様子は見当たらなくなり、休 坐の家具が㢺台となった。椅子に伴った椅坐はまだ社会の一部、特 に上流階層の一部にとどまり、社会全体には普及していなかった。

\section{3-4. 椅坐の定著}

北宋後期、「海明上河図」に示されたように、机・腰掛け等椅坐 に適した家具が都市の店舖で広篹に使用された。しかも、飲食店の 机・腰掛けの使用に一つの新しい変化も現れた。二人が一つの机を はさんで各自の腰掛けに坐り、交流しやすい「对坐」するようになつ たのである（図13）。当時の都市の中の飲食店に関する文献記録に も、この現象が記されている。

“州東仁和店新門里会仙酒楼正店, 常有百十颜館, 動使各各足備, 不尚少開一件。大抵都人風俗奢侈，度量稍充，凡酒店中不論何人一 止画入対坐欲酒, 亦須用注、挽一付……" 和) 〈会仙酒楼の店内に

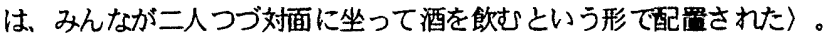

“石曼卿䃌落奇才, 知名当世、乘貌雄偉, 飲酒過人, 有劉潜者, 亦志義之士也, 当与曼卿為酒敵, 閏京師沙行王氏新開酒楼，遂往造 琶、対拎終日。”65）（石曼卿と劉潜が、王氏が酒楼を開店したこ とを閏き、足を運び、一日対坐で酒を飲む〉。

北宋以前、中国の都市道路两側では、閉鎖的な土壁が立てられ、 商業活動は綮しく制限された。北末になると、商品経済が活発にな り、土壁が段々壊され、道路へ直接に面する店舖が数多く現れ、都

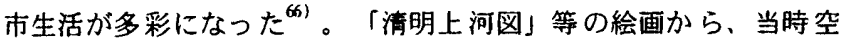
前に繁栄した都市生活の具体像が分かる。飲食店の数多くの出現は 
その中の一側面であった。「対坐」の配置方式は、この時期に関す る他の文献記録と絵画にみられる家庭・官舎・寺院には発見できな かったことから、「対坐」が最初に現れたのは、都市の店舗、特に 飲食店における一般的な配置方式であったと考えられる77)。

「対坐」は、北宋当時、大幅に発達した商品経済、かなり豊かに なった都市生活、空前に発達した庶民文化等という時代背景と緊密 に関わったのではないかと考えられる。

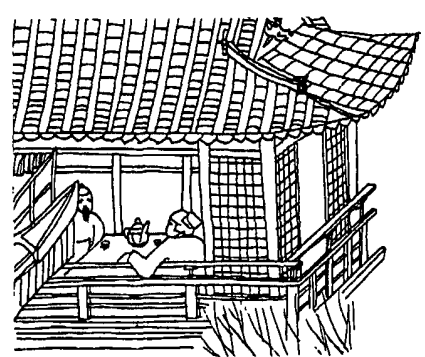

図13 対坐の様子 ${ }^{68}$

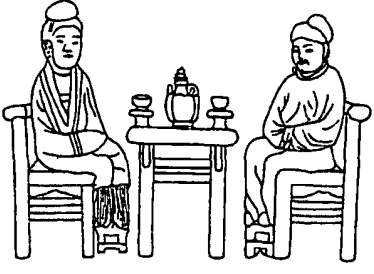

図14 対坐の様子 ${ }^{69)}$
最初、家庭に「対坐」が現れたのは、1100年頃のことであった。 家で宴会する時、夫婦二人が各自一つの椅子に坐り、中央に一つの 机が膡かれ、歌舞を観賞している様子が初めて見られる（図14）。

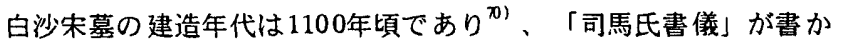
れた年代よりわずか十数年後 (注 ${ }^{62)}$ 参照) のことであるから、家 庭で夫婦対坐の配置は白沙宋墓の建造時期、即ち北宋後期に、まだ 流布し始めたばかりであったと推定できよう。

飲食店の「対坐」の配置方式がようやく家庭に影響を及ほしたの であろう。家庭での日常飲食の時、椅子・机は分離されたものでは なく、一体になり、システムとして成り立ったと言えよう。

北宋後期・南末初期の絵画から、椅坐に基づいた室内の家具の配 膡が社会全体に一般化されたことが分かる。「清明上河図」はこの 中の一つの好例である。高級料亭から一膳飯屋まで、家具の配置は、 いずれも、四角い机と腰掛けの組み合わせで、現在と基本的に同じ であった。椅坐の様式と椅坐に適した家具の配置が都市・農村の店 舗に広く普及した。

又、家庭にも、椅坐に適した家具の配置が一般化された。対称と 非対称との二種類がある。起居室・応接室には、屏風の前方中央に 二つの椅子が置かれ、両側に各四つの椅子が並べられた（図15）。 もしくは、屏風の前に、二つの丸い腰掛けが置かれ、賓主対坐となっ た。書斎、寝室には、非対称の配置が採用された（図16）。

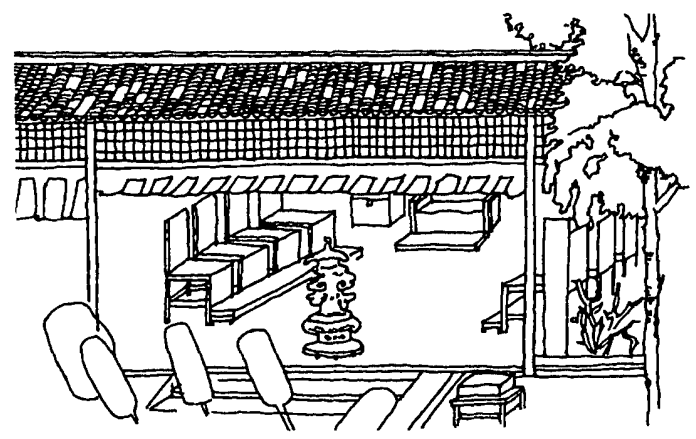

図15 南末の室内家具配置 ${ }^{73}$

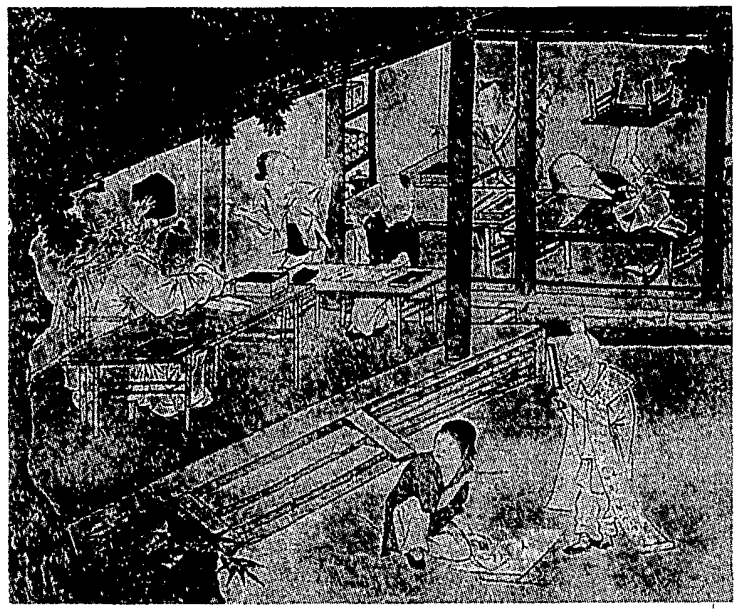

図16 南宋の室内家具配固 ${ }^{72)}$

南末初期、民間の家庭における婦女の.日常生活について、以下の ような記録があった。“今猶有高鏡台、蓋施床則與人面適平也。云 禁中尚用之，特外間不復用爾。”か)〈今なお見られている高い化 粧台が、寝台の上に置かれると、人の顔の高さと等しくなる。これ が宮廷ではまだ使用されていて、外部ではもう使用されていない〉。

これに関連して、北宋後期の椅坐に適した高いたんす、高い「幾」 も初めて発見され、寝台の上に置かれていた、床坐に適した化籸台、 衣析、たんす等の家具が高くなり、床に置かれるようになった ${ }^{74}$ 。

北宋後期 - 南宋初期、民間の家庭で婦女が化粧する等の日常生活 が床坐ではなく、椅坐で行われたと推定できよう。

この段階では、即ち、北宋後期・南末初期、椅坐は社会全体に普 及し、椅坐に適した新しい家具が数多く誕生し始め、机・椅子等の 家具の配置方式は、システムとして、形成され始めた。

しかし、その後、「席」あるいは寝台上での床坐の様子が完全に 消えたわけではなかった。少なくとも、南宋初期、農村の家庭に、 この床坐の様子がまだ見られる（図17）。

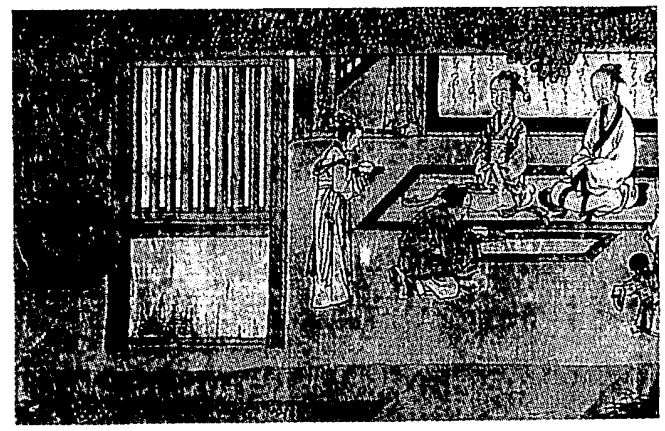

図17 南宋初期の床坐の様子 ${ }^{751}$

\section{4.坐の様式と床の構造}

中国古代建築における、床の構造についての変遷は、高床と非架 構床との二種類から、非架構床の一種類への移り変わりであると考 えられる。このような構造的な变遷が、人間の坐の様式の変化と深 く関わっていると考えられる。墨子は「宮室之法、高足以避濕潤」 と語っている。宮殿を建てる際、湿気の上昇を防ぐため、地面の上 に床を架構し、下に空気を通らせるという意味である。このような 
高床構造はまさに床坐の行動方式に適している。漢代の画像磷から、 当時の高床栱造の様子が見られる（図18）。床坐の習慣が継統され た南北朝でも、同じく高床の構造であった（図19）。

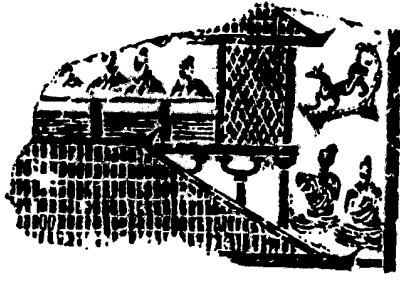

図18 漠代の床構造 ${ }^{76)}$

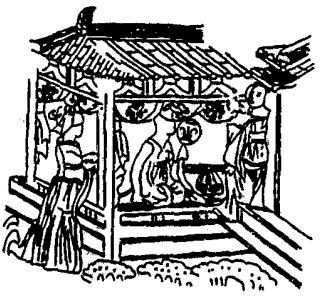

図19 南北朝の床構造 ${ }^{77)}$
唐代になると、地面にタイルを舗装した、非架構床の構造をもつ 建物が多数現れ、絵画等の資料から、高床の姿はほとんど見出すこ とができない（図9参照、図20）。この構造の変化が椅坐の定着よ り早かった理由としては、坐る家具としての垵台の存在にほかなら ない。夏台が休坐と掎坐ともに使用され、これによって、人間の身 体が床から離れるようになり、坐るための快適さが保障されたわけ である。その上、椅子の使用によって、湿気が体に影䇺するのを防 ぐための高休式構造の必要性はさらに少なくなってしまったのであ る。非架構床の数多くの出現と当時徐々に流行してきた椅坐の様式 との関わりは否定できないと思われる。

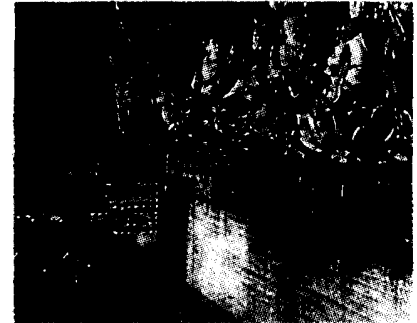

图20 唐代の仏光寺 ${ }^{78)}$

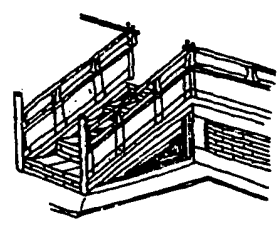

図21 末代の床構造 ${ }^{79}$
椅坐の様式が社会の全体に普及した北末後期から、湿気を防ぐた めの高床の存在意義は失われてしまったので、建物の土台は土、石 林、娻瓦等で诰られ、非架構休の棤造に变わった。「営造法式」》 の規定によって、架構でない「須弥座」 ${ }^{81)} の$ 床の構造が定着した。 末以降、元、明、清に至るまで、このような中国古代建築の床の構 造の形式が続けられた（図21、図16参照）。

最初のうち、椅子と椅坐の導入のきっかけは、漠民族と北西少数 民族の交流・融合だったということであるが、椅坐が次第に拡大 ・ 定畕した最終状況まで、坐の様式と床の構造との二つの要秦は相互 に影整し、要因となり傎きかけたと思われる。椅坐が普及してきた 過程の中で、床坐に適した高床の存在意找第に希薄になってし まった。いわば、坐の様式（行動）が床の構造（環境）へと謿きか けたのである。一方、非架構床の上では、床坐よりも、むしろ椅坐 が適合し、このように床の構造（環境）から坐の様式（行動）への 逆の倒きかけもあったのである。大きな流れを見ると、人間は能動 的に椅坐もしくは床坐という行動様式を選んだり、椅坐もしくは床 坐に適した家具を配置し、高床もしくは非架構床という環境をつくつ たりして、最終的に、床坐をやめて、椅坐を採用したのに伴い、家
具類のシステムを変化させ、「営造法式」によって「須弥座」を規 定した。したがって、人間・環境・行動は分離された独立の檑では なく、千年近くの時間の変化の中で、トランザクショナルなシステ ムの全体として統合され、新たなシステムに変わっていったのであ $3^{82)}$ 。

\section{5.まとめ}

・坐の様式の变息過程（表）及び要因

唐代・五代頃以前、古代中国人の坐の様式は主に床坐であった。 東漠末期から両晋・南北朝にかけて、北西少数民族から伝えられて きた椅坐の様式は、長い歴史の流れの中で、休坐と併用された。北 宋後期・南宋初期に至って、椅坐の様式は社会全体に広がり、よう やく商・周以来の千年近くにわたった床坐の様式に代わった。

表 坐の様式の変悉過程

\begin{tabular}{|c|c|c|c|c|c|}
\hline 䂑傮 & 西庶 & 時期 & 坐の樣式 & 床の㩲遗 & 案县粪型 \\
\hline 林坐の時代 & $\begin{array}{l}\text { 約紀元前16-前11 世紀 } \\
\text { 約紀元前11世紀-前476年 } \\
\text { 前475年-前221年 } \\
\text { 前221年-前206年 } \\
\text { 盟206年-220年 }\end{array}$ & 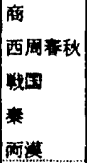 & 㦿坐 & $\begin{array}{l}\text { 恋床 } \\
\text { 非架櫵休 }\end{array}$ & 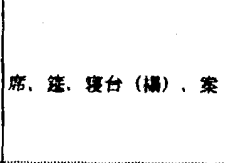 \\
\hline 坐の出現 & $\begin{array}{l}220 \text { 年-280年 } \\
265 \text { 年-420年 } \\
420 \text { 年-589年 } \\
581 \text { 年-618年 } \\
618 \text { 年-907年 }\end{array}$ & 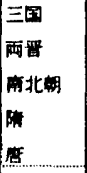 & $\begin{array}{l}\text { 東坐 } \\
\text { 椅坐 }\end{array}$ & $\begin{array}{l}\text { 高㷊 } \\
\text { 非架器床 }\end{array}$ & 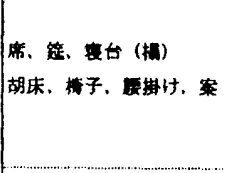 \\
\hline 椅坐の㹡大 & $\begin{array}{l}907 \text { 年-960年 } \\
960 \text { 年-1100年 }\end{array}$ & $\mid$\begin{tabular}{|} 
五代 \\
北宋中短
\end{tabular} & $\begin{array}{l}\text { 床坐 } \\
\text { 菏坐 }\end{array}$ & 非架權林 & 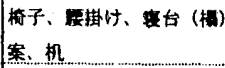 \\
\hline 奇坐の定兼 & $\begin{array}{l}1100 \text { 年-1127年 } \\
1127 \text { 年-1190年 }\end{array}$ & \begin{tabular}{|l|} 
北宋後期 \\
常束初期
\end{tabular} & 椅坐 & 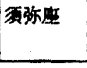 & 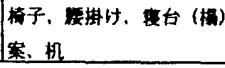 \\
\hline
\end{tabular}

椅子と椅坐の出現のきっかけは、東漠末期からの漠民族と少数民 族との交流・融合である。椅坐の定着には、宋代、発達した商品経 済、豊かになった都市生活などの時代背景と緊密に関わったのでは ないかと考えられる。

·床坐の特幑

中国における、床坐は、床面に坐るか、もしくは寝台に坐るかと いう二種類があった。中国の床坐とは、「寝台坐」でもあった。坐 る家具としての垵台の存在によって、非架構床の出現は早かったの ではないかと思われる。

\section{・坐の様式と床の構造}

中国古代建築の床構造の变要が坐の様式の変遷と祭密に関わった と考えられる。人間・袈境（休の櫣造）・行動（坐の様式）は互い に分離することは不可能なものであり、トランザクショナルなシス テムの全体として統合され、新たなシステムが生まれたのである。

・日中襄境行動の比較

日本では、古代の建物に土間があり、人が坐卧場所だけに板数を 設けたという形から、現在、全面に量を教き詰めるという形へ変わっ た ${ }^{81}$ 。この床構造の変化は、中国の床構造の変化と比べれば、本 貿的な変化はなかったと言えよう。林坐も終始主流として定着した。 床坐（行動）と床の構造（環境）とは一つの安定したシステムでは ないかと思われる。中国では、坐の様式（行動）と床の满造（環境） ともに大きな変化が現れ、新たなシステムに変わったのである。 
注釈・参考文献

1「建管大辞典」彰国社 1993年6月 p 76「椅子式」とは「机、椅子、ベッ ドなどを使用する生活様式。我が国の伝統的な生活栚式としての座式に対し ていわれる。古くからヨーロッパを中心に行われており、我が国でも古代か ら份教風や宮殿風の椅子があったが、本格的に導入されたのは明治年間で、 官公庁、学校、事務所、映画館、上流住宅などで始まった」とされている。 2）前揭畫1) p 632 「座式」とは「生活様式の一。椅子やベッドなどを使 わず、床の上に直接座ることを生活の基本にするもの。日本の伝統的生活栚 式もこの一つである。家具および調度として移動容易な座布団や短足の机、 卓などが用いられる。」とされている。

3）沢田知子「イス坐家具導入過程からみた起居様式の指向性」日本建築 学会計画系論文報告集 第438号 1992年8月 p 35、p 39

4) 入澤達吉「日本人の坐り方に就きて」「史学雑誌」第31編第8号 大正9年8月

5) 山折哲雄「「坐」の文化諭」講談社 1984年12月

6) 芦原義信「街並みの美学」岩波書店 1990年3月

7)芦原菜信「続・街並みの美学」岩波書店 1990年11月

8）沢田知子「起居様式の指向性別による「しつらい」配置形悲の特徽」

日本建筑学会計画系諭文報告集 第452号 1993年10月

9) 沢田知子「起居槺式の指向性別による居室構成ならびに住まい万の特徵」 日本建学会計画系諭文集 第468号 1995年2月

10）笅敦楨「大壮室筆記」中国営造学社匯刊」第三巻第三期 1932年 11）胡床：中国古代，北西少数民族から伝えられた軽便な折りたためる坐具。 胡：中国古代漢民族が北西少数民族に対して用いた総称。休：中国話で寝台 を指す。

12）藤田豊入「胡床につきて」「東西交涉史の研究・西域編及附編」

岡書院 1933年に3月 p 158

13）劉敦槕蝙「中国古代建築史」中国建築工業出版社 1984年6月

14）「中国建築史」編集組編「中国建筑史」中国建築工業出版社 1986 年7月 $\mathrm{p} 118$

15) 席：むしろ。

16）林：寝台、同中国語の「休」。

17）樶：低い宴右。

18）朱恵良「中国人の生活と文化」二玄社 1994年2月 p 136 19）前掲晢1） p 76 「椅子座位」とは「人体計湘の基本になる姿勢の一。 椅子に腰掛けたときの姿竻をいう。従来は倚（い）坐位と呼んでいたが、日 本人間工学会は計測のときは、椅子坐位」と呼ぶことを提案し、次のように 規定している。「背すじを自然に伸活した姿勢で、腓（ひ）骨頭の高さに合 わせた台の上に䁏掛ける。頭部は耳眼水平位で、目は前方を注視する。左右 の大腿をほぼ平行にし、手は軽く握って大腿上面に置く。足底は床面に平ら に着け、瞅の角度はほほ值角になるようにする。」と定義された。

20) 宿 : 宿る。

21) 前揭書13) p 31

22) 案 : 長形の机。

23) 幾 : 小さい机。

24）前揭書 13) p 39

25）(春秋）孔子著 吉川幸次郎注「論語・郷党第十」 朝日新間社 1977年1月

26）(戦国) 荘周「荘子・斉物論第二」「百子全書」光緒紀元夏月湖 崇文書局

27）李文信「邀陽発現的三座壁画古暮」「文物参考資料」1955年第5期

28）笽 : むしろ。

29）西漢では、1尺=0.23 0.234メーター、二尺賖は四十センチ以上である。

30）（漢）劉歆著向新陽・劉克任校注「西京雑記校注・照陽殿」上海 古籍出版社 1991 年5月

31）其股：其踞ともいう。両足を算の形に投げ出して坐る。無作法な坐り方。

32）（西晋）陳寿「三国志・魏志・管察伝」（宋紹熙刊本）

33）前掲書12) $\mathrm{p} 143$

34）（東晋）碩愷之「女史筬図」により作成

35) 前揭書 12) $\mathrm{p} 158$

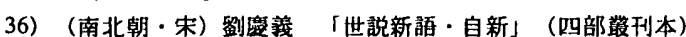

37）（南北朝・北魏）木版渿画「列女古堅図」により作成

38）（南北朝 - 北䖽）敦煌壁面257窟「須摩提女縁品」により作成。この窟は
敦煌石窟初期のもので、漢民族の影響はまだほとんど受けていなかったと考 えられる。この壁画は外道の裸身男性の者が仏に帰体したという物峺である。 39）（南北朝・西魏）敦煌壁画285笜「説法図」により作成。西魏大統4-5 年 (538-539年) 頃完成したこの笜に中原檨式が強く反映されたと考えられる。 40) 同注34)

41）（唐）周昉「掩扇仕女図」により作成。本図では省略したか、右端の 椅子に坐っている女性は付人に世話されており、高貴の人物と判断される。

42）（唐）張萓「捣練図」により作成

43）（唐）敦煌壁画217窟「法華経変」により作成

44）（北宋）王讙「唐語林」巻6

45）宿白「白沙宋蓦」文物出版社 1957年9月 p 101

46）(後曋) 劉呴「旧唐書」12巻「德宗紀」によると、“（建中）四年春

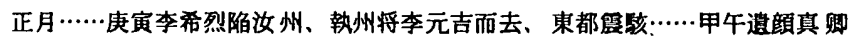
宣怤李希烈軍。”之記録された。783年春正月、李希烈軍が汝州を攻略し、州 将李元吉を捕まえ、東都を驚かせた。䫀真卿がなだめるため、そこへ派遥さ れたという。

47）綿床：胡床の一種類、綶で編んだ。

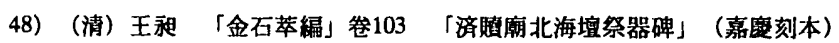

49）（五代）碩閶中「暲熙載夜宴図」により作成。この絵は南唐（902-970

年）の幸相晖熙载が宴を催した場面の真実に近い描写だとされている。

50)（北宋）「浴哭図」により作成

51）(北宋）「仕女梅牧鏡」「秐林月刊」50期 中国画学研究会

52）前揭書48）巻119「慈州武安県定晋山重修古定晋旿禅院千佛邑碑記」

53）（北宋）欧䡃修編「新五代史記」穵29「贯延廣傳」

54）（北宋）丁㯰「丁晋公談録」（涵芬楼排印説䣋本）

55）（北宋）王跮「黙記」

56) 柴荊 : いばらのさく。

57) 晒 : 笑う。

58）（北宋）張凿民「画罢録」（稗海本）

59）土大夫：中国封建時代の官僚、時に讜書人をも含む。

60) 兀子 : 低い喓掛けである。

61）（南宋）陸游 李剣雄・劉德権校「老学庵筆記」厽4 中華書局 1979 年11月 $\mathrm{p} 47$ この書は南宋初期の淳熙年間（1174-1190年）に書かれたど考 えられている。

62）（北宋）司馬光「司馬氏書儀・婚儀」巻4「婦見買姑」司馬光仕北宋 五宗元祐元年（1086年）に死去した。この書は彼晚年の著作だと考えられる。

63) (北宋) 彭乗「墨客揮犀」爷7 (稗海本)

64）（北宋）孟元老「東京著華録」巻4「会仙酒楼」（元刊本）

65）（北宋）欧陽修「帰田䟿」穵2

66）賀業鉅「中国古代城市規㖶史㻅裳」中国建築工業出版社 1986年9月 p 200

67) 前揭書45) $\mathrm{p} 94$

68）（北宋末）張擇端「清明上河図」に上り作成。この絵は、北宋後期の 宣和年間（1111-1 125年）、首都である開封の繁華な状況を描いた有名な絵で ある。しかし、この絵には椅子は見当たらない。

69）前揭㫪45）版図22により作成

70) 前揭菁45) p 81

71）（南宋初）趋伯駒「漢宮図」により作成。この絵か就宗（1127-1 162年） に宫廷画家に任命された時、描かれたと考えられる。

72）（南宋）「村童閙学図」（明・仇英模写）

73) 前掲書61) p 47

74) 前揭書 45) p 94

75）(南宋初) 馬和之「孝経図」

76)「江落銅山画像嘈」前掲書13) p 70

77)「洛陽窂檚石室石彫」前揭書13) p 88

78）仏光寺は現存の唐代の建物で、後代の建替が行われても、変えられたと ころが少なく、当時の様子のままであると考えられる。

79）（北宋末南宋初）李唐「晋文公復国図」により作成

80）（北宋）李諴「営造方式」：北宋崇察二年（1103年）、政拊が建筑物 の建造を管理するため、建築設計・槽造・材料・施工に関した建築基準法と して発布した。

81）須弥座：土、石等で建てられた中国古代建築物の土台。

82）舟橋國男「睘境行動論の視点から」「建笑雑誌」1997年6月号

83）「古事類苑・居處部十六・休」吉川弘文館 1969年7月 p 1063

(1998年 5 月 8 日原稿受理, 1998 年 10 月 22 日採用决定) 